\title{
Membangun Merek Melalui Penyelenggaraan Sebuah Event: Studi Kasus Pada Event "Sour Sally Just Wanna Have Fun"
}

\author{
Prida Ariani Ambar Astuti \\ Program Studi Ilmu Komunikasi \\ Universitas Pelita Harapan
}

\begin{abstract}
A brand enables customers to remember the core information about a product, and prevent competitors from making imitations (Aaker, 1991). Successful brand building helps profitability by adding value that entices customers to buy (De Chernatorny and McDonald, 1994). It is also becoming clearer that companies creating strong brands can obtain important competitive advantage over those that do not (Kohli and Thakor, 1997). Event more firms and other organizations have come to the realization that one of their most valuable assets is the brand names associated with their products or services. Brands themselves may be linked to other entities that have their own knowledge structures in the minds of consumers. A brand may seem more likable or perhaps event trustworthy or expert by virtue of becoming linked to an event. The result showed that the event "Sour Sally Just Wanna Have Fun" can strongly affect the brand of the members that joined in the Facebook group. Through the stages in brand building blocks namely at the stage of salience $70.69 \%$, performance $74,04 \%$, judgments $73.72 \%$, feelings $69.79 \%$, and resonance $64.44 \%$.
\end{abstract}

Key words : brand, event, social network

\section{Pendahuluan}

Brand telah menjadi elemen penting bagi kesuksesan sebuah organisasi dalam memasarkan suatu produk. Istilah brand muncul karena persaingan produk semakin tinggi dan menyebabkan perlunya penguatan pada brand untuk membedakan produk tersebut dengan produk lain. Salah satu upaya perusahaan untuk memperkuat produk/ layanan yaitu dengan branding. Brand ataupun branding dibangun oleh banyak faktor dan dikomunikasikan melalui aspek integrated marketing communication seperti misalnya melalui iklan, event, atau promosi. Komunikasi pemasaran merupakan faktor yang sangat penting untuk membangun brand yang positif (Business \& Accounting, 2010).

Beberapa contoh perusahaan yang sukses dengan brand yang kuat yaitu Apple, Pixar/Disney, Nike, McDonald, Coca Cola dan BMW. Apple sebagai salah satu brand yang kuat berupaya untuk membuat bahwa "Apple" lebih dari sekedar produk. "Apple" menawarkan sebuah gaya hidup yang bersifat hip dan fun atau berupaya untuk membuat kita percaya seperti itu, sehingga produk tersebut memenuhi kebutuhan yang lebih dari sekedar produk (Big girl branding, 2010). 
Brand adalah suatu nama, istilah, tanda, simbol, desain, atau gabungan dari elemen-elemen tersebut yang tujuannya untuk mengidentifikasi suatu produk atau jasa dengan kompetitornya.

A brand is a "name, term, sign, symbol, or design, or a combination of them, intended to identify the goods and services of one seller or group of sellers and to differentiate them from those of competition (Keller, 2008:2).

Branding juga merupakan keseluruhan pengalaman dan persepsi konsumen/prospek pada brand yang dapat kita pengaruhi melalui marketing (About 2010). Brand yang kuat pada sebuah produk atau layanan dapat meningkatkan pertumbuhan penjualan sedangkan branding sebuah perusahaan dimaksudkan untuk menarik dan mempertahankan employeee yang terbaik (About 2010).

Branding dapat mencangkup berbagai hal seperti physical goods: business to business produk dan high-tech produk, layanan, retailers, usaha online, sports, art, entertaiment, lokasi geographic, ideas dan causes, serta people, dan organisasi (Keller 2008:10-26). Seperti yang sudah dinyatakan di atas bahwa brand dapat dibangun oleh banyak faktor dan dikomunikasikan melalui aspek integrated marketing communication seperti misalnya melalui penyelenggaraan sebuah event.

Event menjadi salah satu strategiyang dapat memberikan pengaruh positif yang cukup besar dalam mengkomunikasikan pesan suatu brand kepada masyarakat, terutama kepada target khalayaknya. Dilihat dari sudut pandang customer, brand menempati tempat yang berbedabeda dibenak mereka, tergantung dari persepsi masing-masing customer terhadap brand tersebut.
Menggunakan event sebagai salah satu strategi komunikasi dalam menghadapi persaingan yang ketat juga dilakukan oleh PT. Berjaya Sally Ceria sebagai perusahaan pemilik produk yogurt Sour Sally. Event bertema "Sour Sally Just Wanna Have Fun" bertujuan untuk memperkenalkan konsep kudapan gaya hidup sehat di Indonesia dengan berisi peluncuran beberapa inovasi terbaru dari Sour Sally meliputi: "Sally in the Closet By Diana Lee" yang merupakan sebuah konsep fashion dan apparel yang didesain oleh perancang muda Diana Lee, yang akan diperagakan oleh Cosmo Girl of The year 2009 sesuai dengan gaya khas Sour Sally yang unik, "Sour Sally on your Spot" yang memperkenalkan jasa terbaru dari Sour Sally berupa sistem catering service untuk hadir memenuhi keinginan penggemarnya di hari-hari special seperti anniversary, birthday party dan wedding, "Sour Sally Cheerz Bite" yang merupakan produk inovasi terbaru dari Sour Sally untuk menyambut hari Valentine di bulan Febuari 2010 yang menyajikan perpaduan produk antara cheese cake dan yoghurt untuk memuaskan keinginan para penggemar Sour Sally, dan "Blackberry Application" yang merupakan peluncuran sebuah aplikasi baru di perangkat Blackberry agar para penggemar dapat selalu up to date terhadap info dan promosi yang akan diadakan oleh Sour Sally.

Melalui event Sour Sally Just Wanna Have Fun, Sour Sally berupaya menyampaikan pesan bahwa brand Sour Sally memiliki suatu keunikan dan diferensiasi yang dapat membedakan produknya dengan kompetitor karena adanya inovasi-inovasi baru tersebut. Sour Sally ingin agar masyarakat nantinya dapat menerapkan "Gaya Hidup Sehat a La Sour Sally" (Danny, 2010).

Event "Sour Sally Just Wanna Have 
Fun" ini diselenggarakan di Grand Indonesia Shopping Town East Mall pada hari Jumat, 5 Febuari 2010 dan dimeriahkan oleh penampilan Audy serta Abdul and The Coffee Theory, dan dipandu oleh Addry Danuatmadja. Target market dari event "Sour Sally Just Wanna Have Fun" ini mencakup segala usia yang dimulai dari pelajar, mahasiswa, profesional muda, keluarga, penikmat kuliner hingga penyuka hang-out. Melalui pendekatan brand yang inovatif serta menjadi trendsetter dan inspriasi bagi industri lainnya, misi transformasi healthy lifestyle adalah salah satu goal signifikan yang menjadi nafas hidup Sour Sally untuk kedepannya.

Dari uraian di atas, peneliti ingin mengetahui cara membangun brand melalui penyelenggaraan sebuah event Sour Sally Just Wanna Have Fun.

\section{Konsep dan Teori Terkait}

\section{Brand}

Sama seperti halnya manusia, sebuah produk atau jasa membutuhkan tanda pengenal, yang dapat berupa nama, simbol, karakter, dll. sehinga bisa dengan mudah diingat oleh konsumen, selain juga sebagai media identifikasi yang membedakan suatu produk atau jasa terhadap pesaingnya. Dilihat dari sudut pandang konsumen, brands memiliki nilai yang sangat penting karena konsumen cenderung akan mencari brands yang paling memuaskan keinginan mereka hingga akan mendorong mereka untuk membuat keputusan dalam membeli sebuah produk. Keputusan pembelian suatu brand antara orang yang baru pertama kali (prospect) menggunakan brand tersebut berbeda dengan orang yang sudah pernah (customer) mengkonsumsi brand itu sebelumnya. Duncan (2005:134) membedakan definisi prospect dan customer sebagai berikut:

A prospect is a person who has never bought a brand but might be interested in it. A customer is a person who has purchased a brand at least once within a designated period.

Dilihat dari sudut pandang perusahaan, memotivasi prospek konsumen untuk membeli suatu produk pertama kalinya merupakan suatu proses untuk memperoleh customer. Oleh karena itu, penting sekali dilakukan identifikasi terlebih dahulu terhadap publik atau market yang dituju karena pengetahuan suatu brand menempati tempat yang berbeda di benak publik tergantung dari persepsi masing-masing individu dan perbandingannya dengan brand kompetitor yang serupa. Market sendiri memiliki pengertian sebagai para pembeli aktual dan potensial yang memiliki minat, pendapatan yang cukup, dan akses ke produk (Keller, 2008:99). Bagi konsumen, brand dapat mendorong konsumen untuk membedakan suatu produk dengan produk sejenis lainnya sehingga dapat tercapai decision-making, sedangkan bagi perusahaan, brand dapat menciptakan awareness masyarakat akan suatu produk.

Kunci utama dalam membangun sebuah brand adalah kemampuan untuk memilih nama, logo, simbol, kemasan, dan karakteristik lainnya yang dapat mengidentifikasikan suatu produk dan membedakan produk tersebut dengan yang lainnya. Clow and Baack, mendefinisi brand sebagai berikut:

Brands are names generally assigned to a product or service or a group of complementary products while a corporate image covers every aspect of the company (Clow and Baack, 2004:36). 
Sementara American Marketing Association (AMA) mendefinisikan brand, yakni:

A brand is a "name, term, sign, symbol, or design, or a combination of them, intended to identify the goods and services of one seller or group of sellers and to differentiate them from those of competition (Keller, 2008:2)

Semakin baik image atau citra dari suatu brand yang ada di mata customer, maka semakin tinggi reputasi suatu perusahaan. Brand yang baik tidak hanya memperhatikan nama dari brand tersebut, melainkan mempertimbangkan elemen lainnya seperti logo dan simbol.

Meskipun demikian produk bukanlah brand. Produk adalah segala sesuatu yang dapat ditawarkan untuk menarik perhatian pasar, untuk dipakai dan dikonsumsi agar memuaskan apa yang diinginkan oleh konsumen.
Sedangkan brand lebih dari sekedar sebuah produk, karena ia memiliki dimensi yang membedakannya dengan produk lain, yang dirancang sedemikian rupa untuk memenuhi kebutuhan yang sama (Keller, 2008:3).

\section{Brand Building}

Struktur dalam proses membangun sebuah brand atau biasa dikenal dengan "brand building". Proses brand building meliputi tahapan dari brand building blocks dan subdimensi dari building blocks dalam bentuk sebuah piramida. Building blocks sisi kiri piramida lebih menggambarkan rute yang rasional dalam brand building, sedangkan building blocks dari sisi kanan piramida cenderung lebih mengarah kepada rute yang emosional. Oleh karena itu, brand yang kuat adalah brand yang sebagian besar dibangun oleh kedua sisi dari piramida tersebut.
Stages of Brand Development

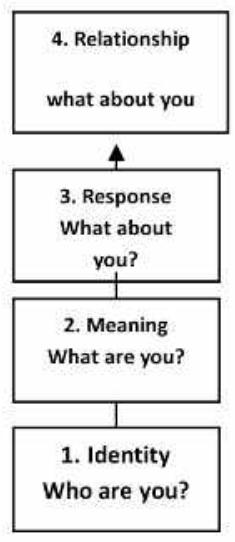

Branding Objective at Each Stage

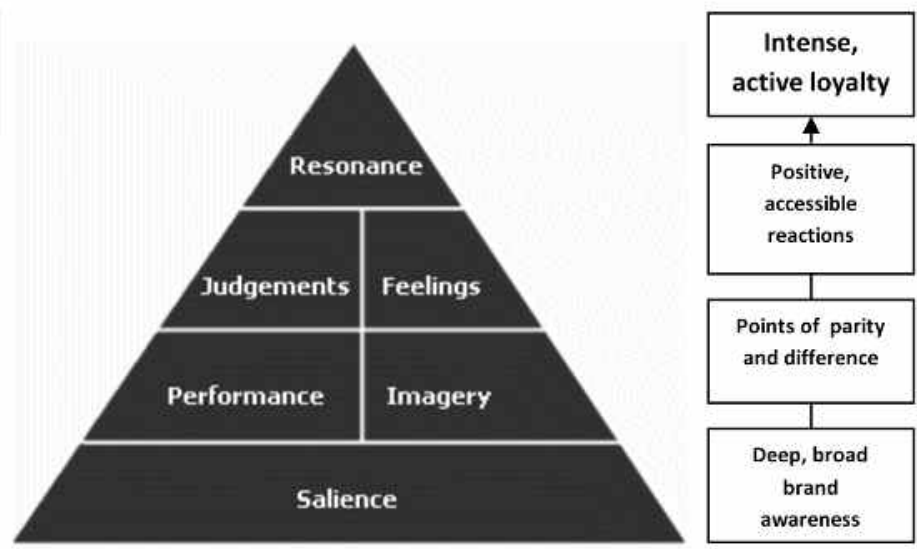

Gambar 3.4. Customer-Based Brand Equity Pyramid

Sumber: Keller, 2008:60 


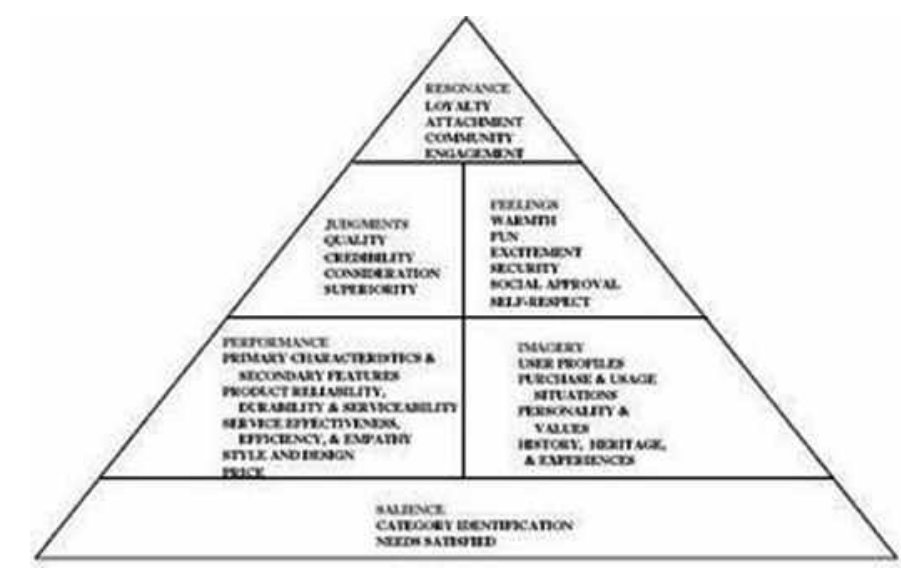

\section{Gambar 3.5. Subdimensions of Brand Building Blocks}

Sumber: Keller, 2008:61

Tahap pertama dalam brand building adalah "Brand Salience", dimana dalam tahap ini, pencapaian brand identity yang baik berarti menciptakan arti penting suatu brand bagi customer. Brand Salience mengukur awareness dari sebuah brand, seperti sejauh mana sebuah brand menduduki top-of-mind sehingga brand tersebut mudah untuk diingat. Dengan kata lain, membangun brand awareness dapat menolong customer untuk lebih mengerti akan kategori suatu produk atau layanan yang dijual dengan nama brand tersebut. Melalui brand awareness, juga dapat dipastikan bahwa customer mengetahui secara jelas kebutuhan mereka akan suatu brand melalui produk tersebut, yang diciptakan untuk memuaskan keinginan mereka.

Beberapa kegunaan dasar yang harus disediakan oleh suatu brand kepada customer, yang pertama adalah breadth and depth of awareness, dimana the depth of brand awareness mengukur bagaimana elemen suatu brand dapat datang dan menetap di benak audience sehingga dapat dikatakan bahwa brand yang mudah untuk dipanggil memiliki tingkat yang lebih dalam untuk mencapai brand awareness dibandingkan dengan brand yang hanya dapat kita kenali apabila kita melihat wujud dari brand tersebut. Sedangkan the breadth of brand awareness mengukur beragam pembelian dan situasi pemakaian dimana elemen dari brand tersebut hadir di benak audience dan bergantung pada pengetahuan produk suatu brand di memori konsumen tersebut.

Yang kedua adalah product category structure, yang merupakan bagaimana kategori suatu produk terorganisasi dalam memori, karena di dalam benak konsumen, tingkatan suatu produk selalu ada, dimulai dari produk kelas atas, menengah hingga kelas terendah. Yang ketiga adalah strategic implications, dimana tingkatan kelas suatu produk menunjukkan bahwa tidak hanya the depth of awareness yang memiliki peranan penting, tetapi juga the breadth. Dengan kata lain, suatu brand tidak cukup hanya menjadi top-of-mind, tetapi juga harus berada pada waktu dan tempat yang sesuai. Kunci pertanyaan dari suatu brand tidak terletak pada bagaimana konsumen dapat mengenali brand tersebut, melainkan pada saat dimana dan kapan mereka memikirkan brand tersebut, dan seberapa mudah dan sering mereka 
memikirkannya.

Tahap kedua dalam brand building adalah "brand performance". Brand Performance mendeksripsikan bagaimana suatu produk atau layanan menemukan kebutuhan fungsional customer. Produk sendiri merupakan faktor utama yang mempengaruhi bagaimana konsumen bereksperimen dengan sebuah brand, apa yang mereka dengar tentang suatu brand dari orang lain, dan apa yang dapat diceritakan oleh perusahaan kepada customer mengenai brand tersebut didalam proses berkomunikasi. Oleh karena itu, brand performance melibatkan isi dan tampilan dari suatu produk agar membawa suatu dimensi yang dapat membedakan brand tersebut. Berikut cara customer memandang performance, yakni: reliability yang mengukur performance secara konsisten dari waktu ke waktu dan dari purchase ke purchase, durability yang merupakan ekspektasi ekonomis dari suatu produk, dan serviceability yang merupakan jasa perbaikan dari suatu produk apabila diinginkan. Price juga menjadi salah satu faktor yang penting dalam asosiasi performance karena konsumen cenderung mengorganisasi kategori pengetahuan suatu produk berdasarkan harga yang bervariatif dari tiap brands yang berbeda. Oleh karena itu, prosedur harga untuk suatu brand dapat mempengaruhi dan menciptakan asosiasi di benak konsumen terhadap bagaimana relatif mahal atau tidak mahalnya harga suatu brand.

Tahap ketiga dalam brand building adalah "brand imagery", yang merupakan tipe utama lainnya dari "brand meaning". Brand imagery meliputi cara bagaimana suatu brand mencoba untuk menemukan kebutuhan sosial dan psikologis customer dan tentang bagaimana cara pikir orang terhadap brand tersebut secara abstrak, bukan secara apa yang seharusnya mereka pikirkan tentang brand tersebut. Dengan kata lain, "imagery" lebih mengarah kepada aspek yang tidak berwujud dari suatu brand dan konsumen dapat membentuk asosiasi imagery secara langsung berdasarkan apa yang telah dialami mereka (experience) maupun secara tidak langsung yaitu melalui iklan atau sumber informasi lainnya seperti word of mouth. Berikut empat macam aspek utama yang tidak berwujud yang dapat dihubungkan pada suatu brand, yaitu: user profiles, purchase and usage situations, personality and values, dan history, heritage, and experiences.

Tahap keempat dalam brand building adalah "brandjudgments". Brandjudgments merupakan suatu bentuk opini pribadi dari customer dan sekaligus merupakan evaluasi terhadap suatu brand, dimana konsumen menggabungkan seluruh brand performance yang berbeda-beda beserta imagery associations-nya. Terdapat empat elemen utama yang sangat penting dalam brand judgment, yakni: brand quality yang merupakan evaluasi konsumen secara keseluruhan terhadap suatu brand dan seringkali membentuk suatu dasar untuk pilihan dari berbagai macam brand, brand credibility yang mendeskripsikan sejauh mana konsumen melihat suatu brand secara kredibel dalam jangka waktu tiga dimensi yang berupa perceived expertise, trustworthiness, dan likability, brand consideration yang bergantung pada bagian dimana customer yang bersangkutan secara pribadi menemukan brand tersebut dan menjadi suatu hal yang sangat penting dalam membangun brand equity, dan brand superiority yang mengukur sejauh mana customer memandang suatu brand secara unik dan lebih baik dibanding dengan brand lainnya. 
Tahap kelima dalam brand building adalah "brand feelings". Brand feelings merupakan respon emosional dari customer dan reaksi terhadap suatu brand seperti bagaimana suatu brand memperngaruhi perasaan customer terhadap diri mereka sendiri serta hubungan mereka dengan yang lainnya. Feelings tersebut bisa bersifat positif maupun negatif, tergantung dari masingmasing respon customer terhadap brand tersebut. Terdapat enam elemen penting dalam brand-building feelings, yakni: warmth, fun, excitement, security, social approval, dan self-respect.

Tahap terakhir dalam brand building adalah "brand resonance", yang merupakan langkah terakhir yang berfokus pada hubungan utama dan level identifikasi yang telah dinilai oleh customer terhadap suatu brand. Brand resonance mendeskripsikan sifat dari hubungan ini dan sejauh mana customer merasakan bahwa mereka terikat dengan brand tersebut. Resonance dikarakteristikan dalam hal intensitas atau kedalaman ikatan psikologis yang dimiliki oleh customer terhadap suatu brand maupun aktivitas yang disebabkan oleh loyalitas customer terhadap suatu brand, seperti pengulangan tingkat pembelian suatu produk dan sejauh mana customer mencari tau informasi mengenai brand tersebut. Kedua dimensi tersebut dapat dipecahkan ke dalam empat kategori, yakni: behavioral loyalty dalam hal pengulangan pembelian dan jumlah atau pembagian kategori yang dikaitkan dengan brand, attitudinal attachment dimana customer harus melampaui sikap positif dalam memandang suatu brand secara khusus dalam konteks yang lebih luas, sense of community dimana dengan mengidentifikasi brand community dapat menghasilkan fenomena sosial yang penting sehingga customer dapat merasakan ikatan yang terjadi dengan orang yang berasosiasi dengan brand tersebut, baik terhadap sesama pemakai brand atau customer maupun dengan karyawan atau representatif dari perusahaan, dan yang terakhir active engagement yang menjelaskan bahwa brand loyalty akan tercipta apabila tercapai customer's engagement, dimana customer bersedia untuk menginvestasikan waktu, energi, uang, atau sumber daya lainnya pada suatu brand yang dikeluarkan selama melakukan pembelian atau selama mengkomsumsi brand tersebut.

\section{Brand Audits}

Dalam mempelajari bagaimana konsumen mengenal sebuah brand dan suatu produk sehingga perusahaan dapat membuat sebuah keputusan, pertamatama perusahaan harus melakukan brand audit ke dalam struktur pengetahuan konsumen (consumer knowlege). Menurut Keller (2008:126), yang dimaksud dengan brand audit adalah:

A brand audit is a comprehensive examination of a brand to discover its sources of brand equity.

Brand audit adalah suatu ujian atau pemeriksaan terhadap suatu brand untuk menemukan sumber brand equity dari brand tersebut. Dengan kata lain, brand audit lebih mengarah atau berfokus pada konsumen untuk menilai tingkat kesehatan suatu brand, menemukan sumberbrandequity-nya danmenyarankan cara-cara untuk mengembangkan dan meningkatkan ekuitasnya, namun brand audit juga memerlukan pemahaman dari kedua belah pihak yaitu dari sudut pandang perusahaan dan juga sudut pandang konsumen. Apabila dilihat dari sudut pandang perusahaan, produk 
apakah yang sedang ditawarkan kepada konsumen dan bagaimana produk tersebut dapat dipasarkan, sedangkan jika dilihat dari sudut pandang konsumen, persepsi dan kepercayaan seperti apa yang menciptakan arti sebenarnya dari suatu brand dan produk.

Salah satu langkah yang termasuk dalam brand audit adalah brand exploratory. brand exploratory bertujuan untuk menyediakan informasi yang detil mengenai apa yang dipikirkan oleh konsumen terhadap suatu brand.

The brand exploratory is research directed to understanding what consumers think and feel about the brand and its corresponding product category in order to identify sources of brand equity (Keller, 2008:129)

Dengan kata lain brand exploratory merupakan suatu penelitian yang bertujuan untuk memahami apa yang dipikirkan dan dirasakan oleh konsumen terhadap suatu brand, serta kategori produk yang sesuai unntuk mengidentifikasi sumber brand equity dari brand tersebut. Brand exploratory meliputi empat jenis tipe penelitian atau reserach, yakni preliminary activities, interpreting qualitative research, conducting quantitative research, dan brand positioning and the supporting marketing program.

Conducting quantitative research dapat memberikan penilaian yang lebih jelas terhadap kedalaman dan keluasan akan suatu brand awareness, dan kekuatan, ketertarikan, serta keunikan asosiasi suatu brand, yang seringkali memerlukan tahap penelitian kuantitatif. Pedoman untuk penelitian kuantitatif dalam brand exploratory cenderung tepat pada sasaran. Perusahaan harus dapat memeriksa secara spesifik brand belief dan overall attitudes agar dapat mengungkapkan hasil dan sumber-sumber yang potensial. Perusahaan juga perlu melakukan penelitian yang sejenis bagi kompetitor untuk lebih mengerti bagaimana perbandingannya dengan target brand.

Semua tujuan dari penelitian di atas, baik secara kualitatif maupun kuantitatif bertujuan untuk mengfokuskan pada asosiasi nama suatu brand, seperti apa yang dipikirkan oleh konsumen ketika mendengar nama suatu brand dan bagaimana pandangan mereka terhadap suatu brand jika dilihat dari sisi packagingnya. Dengan adanya penelitian tersebut, perusahaan dapat menjelajahi aspek yang spesifik dari elemen suatu brand sehingga dapat ditentukan elemen manakah yang paling efektif untuk mewakili dan menggambarkan suatu brand secara keseluruhan.

\section{Metodologi Penelitian}

Jenis penelitian ini termasuk penelitian deskriptif, dimana metode deskriptif adalah suatu metode dalam meneliti status sekelompok manusia, suatu objek, suatu set kondisi, suatu sistem pemikiran, ataupun suatu kelas peristiwa pada masa sekarang. Tujuan dari penelitian deskriptif ini adalah untuk membuat deskripsi, gambaran atau lukisan secara sistematis, faktual dan akurat mengenai fakta-fakta, sifatsifat serta hubungan antarfenomena yang diselidiki (Nazir, 2005:54).

Peneliti menggunakan metode penelitian deskriptif karena ingin memberikan suatu deskripsi dan gambaran mengenai realitas terhadap Sour Sally sebagai hasil dari pelaksanaan event "Sour Sally Just Wanna Have Fun". Penelitian ini ingin melihat bagimana persepsi masyarakat yang terbentuk terhadap Sour Sally setelah event 
dilaksanakan .

Metode penelitian yang digunakan adalah metode penelitian survai, dimana informasi yang dikumpulkan menggunakan kuesioner yang datanya dikumpulkan dari sampel atas populasi untuk mewakili seluruh populasi. Dengan penelitian ini diharapkan dapat diperoleh fakta-fakta dari gejala yang ada dan keterangan yang faktual yang didapat melalui kuesioner sebagai instrumen pengumpulan datanya, terhadap keadaan yang telah berlangsung, dan hasilnya diharapkan dapat digunakan dalam membuat perencanaan dan mengambil keputusan di masa mendatang. Oleh karena itu, penelitian dilakukan dengan membagikan kuesioner terhadap sample dari sejumlah populasi yang telah menghadiri event "Sour Sally Just Wanna Have Fun" untuk memperoleh data yang faktual dari gejala atau masalah yang ada.

Target populasi pada penelitian ini adalah anggota yang tergabung di dalam Facebook grup event "Sour Sally Just Wanna Have Fun" yang berjumlah 798 orang. Selanjutnya dengan menggunakan rumus Taro Yamane diperoleh 266 orang sebagai sampel. Teknik pengambilan sampel dilakukan dengan menggunakan teknik sampling accidental sampling yaitu pengambilan sampel dari siapa saja yang kebetulan ada (Nasution, 2007:98).

Peneliti mengambil sampel pada anggota yang tergabung di dalam grup event "Sour Sally Just Wanna Have Fun" di Facebook dikarenakan anggota tersebut dapat memberikan informasi yang lengkap dan jelas mengenai event terutama karena penelitian ini ingin melihat bagaimana image konsumen terhadap Sour Sally pasca event tersebut. Selain itu, pemilihan sampel ini dikarenakan anggota yang tergabung di dalam grup tersebut telah memiliki pengalaman langsung dengan event "Sour Sally Just Wanna Have Fun" sehingga informasi yang diberikan didasarkan pada pengalaman mereka selama mereka mengikuti event tersebut.

Kuesioner akan dihitung oleh Penulis dengan menggunakan skala Likert dan skala tersebut memiliki kriteria angka penilaian yaitu: (1) Sangat Tidak Setuju, (2) Tidak Setuju, (3) Netral, (4) Setuju, dan (5) Sangat Setuju. Jawaban tersebut masing-masing diberi nilai 5, 4, 3, 2, 1 dari yang sangat setuju sampai dengan sangat tidak setuju yang digunakan oleh Peneliti untuk memberikan skor pada item yang terdapat dalam kuesioner. Kemudian dari total skor yang diperoleh, Peneliti akan membagi total skor tersebut dengan skor tertinggi yaitu 5320 (yang diperoleh dari skor tertinggi dalam skala Likert yaitu 5 dikalikan dengan jumlah sampel dalam penelitian ini) dan kemudian dikalikan dengan $100 \%$. Perhitungan ini dilakukan agar Peneliti dapat melihat persentase yang diperoleh dalam setiap tahapan Brand Building. Berikut adalah kriteria interpretasi skornya (Kriyantono, 2008:138) yaitu:

$0 \%-20 \%=$ Sangat Lemah

$21 \%-40 \%=$ Lemah

$41 \%-60 \%=$ Cukup

$61 \%-80 \%=$ Kuat

$81 \%-100 \%=$ Sangat Kuat

Semakin tinggi tingkat persentase yang diperoleh, berarti semakin kuat event "Sour Sally Just Wanna Have Fun" dalam membangun brand.

Data yang telah diperoleh dari kuesioner akan dihitung dengan menggunakanSPSS16.0 for windows untuk diukur apakah hasil yang telah diperoleh telah valid dan reliable. Kuesioner tersebut 
akan dianggap realible apabila nilai yang keluar sesuai dengan perhitungan Alpha Cronbach yaitu minimum di atas 0,5. Selanjutnya setelah kuesioner dihitung, hasil dari kuesioner dikelompokkan ke dalam tabel distribusi frekuensi yang kemudian dihitung dan dianalisis dengan menggunakan konsep brand building.

\section{Hasil Penelitian}

\section{Profil Responden}

Responden terbesar berjenis kelamin perempuan sejumlah 209 orang dengan persentase sebesar $78.6 \%$ dan pria dengan jumlah 57 orang sebesar $21.4 \%$. Kemudian mayoritas usia responden adalah $20 \mathrm{~s} / \mathrm{d}$ 40 tahun dengan jumlah 153 responden, kemudian usia $<20$ tahun sebanyak 68 responden, dan usia $40 \mathrm{~s} / \mathrm{d} 65$ tahun sebanyak 45 responden. Profesi responden kebanyakan adalah sebagai ibu rumah tangga dengan jumlah 105 responden sebesar $39.5 \%$, sebagai karyawan dengan jumlah 76 responden sebesar $28.6 \%$, sebagai pelajar atau mahasiswa dengan jumlah 58 responden sebesar $21.8 \%$ dan hanya 27 responden yang berprofesi sebagai wiraswasta dengan persentase sebesar $10.2 \%$. Sementara berdasarkan tingkat pengeluaran responden terbanyak adalah responden dengan pengeluaran per bulan sebesar Rp 1.250.000 1.750.000 dengan jumlah 147 responden, kemudian terdapat 65 responden dengan pengeluaran per bulan yang lebih besar dari Rp 1.750.000 dan 54 responden dengan pengeluaran per bulan yang lebih kecil dari Rp 1.250.000.

Jenis kelamin perempuan sebagai mayoritas responden dapat dipahami karena perempuan memang lebih cenderung peduli akan gaya hidup sehat, hal ini didukung dengan pernyataan dari
Marcus Kandou selaku Public Relations PT. Berjaya Sally Ceria, bahwa ketika Sally "diputuskan" bergender perempuan, menurut Marcus Kandau adalah karena biasanya yang health conscious itu adalah perempuan. Selain itu, perempuan juga lebih identik dengan kecantikan. Oleh sebab itu, adalah sebuah syarat bagi seorang perempuan untuk bergaya hidup sehat agar senantiasa dapat tampil cantik. Hal ini juga didukung dengan pernyataan dari Sonia Wibisono, seorang model yang juga berprofesi sebagai dokter, bahwa "Kecantikan tidak bisa datang tanpa tubuh yang sehat. Karenanya, kalau kita mau cantik, kita harus menjaga kesehatan dengan bergaya hidup sehat" (Kandau, 2010).

Sementara usia terbesar responden adalah 20-40 tahun hal ini juga tidak mengherankan karena target Sour Sally sendiri adalah pelajar atau remaja, mahasiswa, profesional muda, keluarga, penyuka hang out, dan penikmat kuliner, yang berarti adalah kaum muda dan dewasa (Fact Sheet Sour Sally 2010). Sementara jika dilihat dari tingkat pengeluaran Marcus Kandou menyatakan bahwa "Target market awal kami adalah segmen AB" (Kandou, 2010). Yang artinya target market dari Sour Sally adalah untuk masyarakat kelas menegah keatas.

\section{BrandBuilding Melalui Penyelenggaraan Event}

Terdapat 6 tahapan dalam membangun sebuah brand dan hasil temuan data dalam masing-masing tahapan adalah sebagai berikut: 
Tabel 1 Persepsi Konsumen Terhadap Brand Sour Sally Pasca Event

\begin{tabular}{|l|l|c|c|}
\hline No. & $\begin{array}{l}\text { Konsumen Terhadap Brand Sour } \\
\text { Sally }\end{array}$ & $\begin{array}{c}\text { Nilai } \\
\text { Total }\end{array}$ & $\begin{array}{c}\text { Persentase } \\
(\mathbf{\%})\end{array}$ \\
\hline 1 & Salience & 3761 & 70,69 \\
\hline 2 & Performance & 3939 & 74,04 \\
\hline 3 & Imagery & 3971 & 74,64 \\
\hline 4 & Judgments & 3922 & 73,72 \\
\hline 5 & Feelings & 3713 & 69,79 \\
\hline 6 & Resonance & 3588 & 67,44 \\
\hline
\end{tabular}

Sumber: Nica, 2010.

Dapatdilihat pada tabel diatas bahwa event "Sour Sally Just Wanna Have Fun" dapat dikategorikan berhasil membentuk persepsi positif konsumen terhadap brand Sour Sally. Hal ini dikarenakan pesan yang disampaikan melalui event "Sour Sally Just Wanna Have Fun" dikemas secara kreatif melalui penyelenggaraan event yang menggunakan Fashion Show busana perancang muda berbakat Indonesia, Diana Lee, dengan label "Sour Sally Couture" dan diperagakan oleh finalis CosmoGirl of The Year 2009, serta dibarengi dengan beberapa peluncuran inovasi terbaru dari Sour Sally yakni: Sour Sally On Your Spot, Sour Sally Cheerz Bite, dan Sour Sally Blackberry Application (Nica, 2010) sehingga persepsi konsumen terhadap brand Sour Sally pun menjadi kuat.

Selain itu Sour Sally pun menyadari bahwa untuk membangun sebuah brand yang kuat mereka perlu menetapkan secara spesifik 4 hal penting yaitu identitas merek, arti merek, respon yang diharapkandarikonsumen, danhubungan brand dengan konsumen (Keller, 2008). Dalam tahap identitas merek, Sour Sally selalu menyampaikan pesan bahwa yoghurt Sour Sally adalah kudapan yang sehat sehingga jika tidak dikonsumsi berlebihan tidak akan membahayakan kesehatan. Pesan ini selalu disampaikan kepada konsumen pada setiap aktivitas komunikasi yang dilakukan sehingga efek kognitif dan afektif pun tercapai. Selain itu arti brand name Sour Sally sebagai kudapan yang menyehatkan juga selalu diulang-ulang untuk disampaikan kepada konsumen. Dari aktivitas repetisi identitas dan arti merek tersebut, perusahaan mengharapkan respon konsumen juga mencakup 3 hal, yaitu mereka menjadi tahu bahwa produk Sour Sally menyehatkan dan karena tidak merugikan kesehatan menyebabkan konsumen menyukainya, pada akhirnya rasa suka ini akan mendorong konsumen untuk mengkonsumsinya. Dari sisi membangun hubungan dengan konsumen yang menjadi faktor keempat membangun brand inilah, Sour Sally menyelenggarakan event "Sour Sally Just Wanna Have Fun".

Event dapat digunakan sebagai sarana untuk membangun brand, karena dengan menyelenggarakan sebuah event beragam tujuan dapat dicapai di dalamnya. Demikian juga dalam event "Sour Sally Just Wanna Have Fun" dapat digunakan sebagai salah satu cara untuk membangun hubungan dengan konsumen. Baik tidaknya hubungan antara perusahaan dengan konsumennya dapat diketahui dari respon yang diberikan. Argenti (2007:25) 
pun menyatakan bahwa "The response from the constituencies in question is what is most important. Communication is only successful if you get the desired response from your audience". Dari penyataan ini dapat dikatakan bahwa jika konsumen memberikan respon positif terkait penyelenggaraan event, maka event tersebut dapat dikatakan berhasil atau sukses. Respon ini dapat mencakup kehadiran target publik saat event, keterlibatan mereka dalam aktivitas komunikasi yang dilakukan Sour Sally, dan aktivitas-aktivitas lain yang ditawarkan sebelum, pada saat atau sesudah event tersebut diselenggarakan.

Temuan data juga menyatakan bahwa Sour Sally berhasil menjadi top-of-mind khalayak karena brand mudah diingat. Keberhasilan menjadi top-of-mind ini turut didukung karena terselenggaranya suatu event yang dapat memberikan dampak kepada target sasaran. Event memang dibuat dengan tujuan untuk melibatkan target audience pada program yang diselenggarakan perusahaan dan hal inilah yang mendorong suatu event menjadi sebuah pengalaman yang mudah diingat dan lebih memotivasi karena target audience ikut berpartisipasi dan menjadi bagian dalam event tersebut (Duncan, 2005:608). Duncan lebih lanjut menyatakan bahwa "events are highly targeted brand-associated activities designed toactivelyengagecustomers and prospects and generate publicity. Events can have a major impact because they are involving. This characteristic makes an event more memorable and motivating than passive brand messages, such as advertising, because the people attending are participating in and are part of the event" (Duncan, 2002).

Sementara pada tahap performance, dapat dilihat pada tabel di atas bahwa Sour Sally dapat memenuhi kebutuhan fungsional customer (74,04\%). Kuatnya tanggapan consumer terkait dengan kebutuhan fungsional mereka disebabkan karena event "Sour Sally Just Wanna Have Fun" dikemas dalam bentuk kreatif melalui peluncuran inovasi-inovasi terbaru Sour Sally, dua di antaranya yaitu "Sally In The Closet By Diana Lee" yang berupa fashion dan apparel yang didesain oleh perancang muda Diana Lee untuk memberikan image gaya hidup sehat dengan produk yoghurt, serta layanan "Sour Sally Blackberry Application" sehingga responden merasa lebih mudah untuk mengetahui adanya informasi terbaru mengenai produk dan inovasi terbaru Sour Sally. Pemenuhan kebutuhan fungsional konsumen terkait brand Sour Sally selalu diingatkan melalui pesan yang disampaikan selama event berlangsung yaitu Sour Sally adalah kudapan yang menyehatkan, sehingga jika konsumen mencari kudapan yang menyehatkan mereka bisa mengkonsumsi yoghurt dengan merek Sour Sally.

Tahapan selanjutnya setelah tahap performance adalah tahap imagery. Tahap imagery adalah tahap bagaimana suatu brand mencoba untuk menemukan kebutuhan sosial dan psikologis customers dan tentang bagaimana cara pikir orang terhadap brand tersebut secara abstrak, bukan secara apa yang seharusnya mereka pikirkan tentang brand tersebut. Peluncuran inovasi produk dan layanan terbaru Sour Sally menghasilkan temuan yang mengindikasikan kuatnya tahapan ini pada konsumen (74,64\%). Dari harga produk, rasa, dan acara yang terselenggaraa dalam event dapat dilihat bahwa mereka yang mengkonsumsi produk ini selain akan mendapatkan manfaat fungsional juga akan mendapatkan pemenuhan kebutuhan sosial dan psikologis, karena 
brand Sour Sally tidak hanya berupaya untuk memenuhi kebutuhan fungsional khalayak saja sebagai kudapan yang sehat tetapi juga merupakan produk yang prestisius sehingga konsumen yang telah mengkonsumsi selain mendapatkan kepuasan fungsional juga mendapatkan keuntungan sosial dan psikologis seperti rasa bangga, dan prestise setelah mengkonsumsi produk ini Dengan kata lain, "imagery" lebih mengarah kepada aspek yang tidak berwujud dari suatu brand (Keller, 2008:65).

Setelah mampu memenuhi rasa sosial dan psikologis, tahap judgments adalah tahap terbentuknya opini pribadi customers sekaligus evaluasi terhadap suatu brand. Pada tahap judgments, opini pribadi khalayak telah terbentuk bahwa Sour Sally memang menjadi produk yoghurt yang menyehatkan sesuai dengan pesan yang disampaikan perusahaan sebagai upaya branding. Jika opini publik telah terbentuk sesuai dengan tujuan branding yang telah ditetapkan perusahaan maka dapat dikatakan proses membangun brand yang telah dilakukan berhasil mencapai tujuan dan pada tabel di atas tahap judgment ada pada kategori kuat $(73,72 \%)$.

Event memang diselenggarakan dengan tujuan untuk mendapatkan respon konsumen dan respon ini merupakan tahap feelings yaitu tahap customer memberikan respon emosional dan reaksi terhadap suatu brand. Temuan data menyatakan bahwa konsumen memberikan respon dan reaksi positif terhadap brand Sour Sally (69,79\%). Terdapat 6 elemen penting dalam brandbuilding feelings, yakni: warmth, fun, excitement, security, social approval, dan self-respect (Keller, 2008:69) dan Sour Sally berupaya untuk mewujudkan itu semua melalui penyelenggaraan event "Sour
Sally Just Wanna Have Fun". Adanya perasaan aman (security) pada konsumen disampaikan melalui pesan bahwa setelah mengkonsumsi Sour Sally karena frozen yoghurt Sour Sally mengandung rendah lemak atau low-fat sehingga tidak menyebabkan kegemukan. Selain itu, dengan mengkonsumsi produk Sour Sally, khalayakjuga merasa mendapatkan suatu prestige atau social approval dari lingkungan sekitar. Kemudian dengan adanya beberapa peluncuran inovasi terbaru dari Sour Sally yang berupa jasa layanan "Sour Sally Blackberry Application", khalayak senatiasa merasakan suatu kedekatan (warmth) karena dapat terus meng-update informasi terbaru mengenai Sour Sally, serta dengan adanya sistem catering profesional "Sour Sally On Your Spot", khalayak merasakan suatu kegembiraan (excitement) bahwa Sour Sally dapat ikut hadir dan menemani mereka di hari-hari spesial.

Keterikatan atau relation antara perusahaan dengan konsumen selalu diupayakan agar terwujud dan ini juga merupakan tahap terakhir dalam membangun brand. Tahap resonance merupakan tahap sejauh mana customers merasakan bahwa mereka terikat dengan brand Sour Sally, tahap ini juga merupakan intensitas atau kedalaman ikatan psikologis yang dimiliki oleh customer terhadap Sour Sally maupun aktivitas yang disebabkan oleh loyalitas customer terhadap Sour Sally, seperti pengulangan tingkat pembelian produk dan sejauh mana customers mencari tahu informasi mengenai SourSally (Keller, 2008:72). Hasil temuan data menyatakan bahwa ikatan antara Sour Sally dengan konsumen kuat $(67,44 \%)$, ikatan ini tercipta karena adanya pemenuhan fungsional, sosial, psikologis, dan evaluasi yang positif dari konsumen terhadap Sour Sally. 


\section{Simpulan}

Berdasarkan temuan data dan analisis yang dilakukan terkait penyelenggaraan event "Sour Sally Just Wanna Have Fun" dapat dilihat bahwa event tersebut berhasil membangun merek Sour Sally di mata konsumen. Event memang diselenggarakan perusahaan sebagai upaya membangun hubungan dengan konsumen, karena melalui penyelenggaraan event, konsumen akan dilibatkan dalam program yang diselenggarakan perusahaan sehingga hubungan yang terjalin akan lebih erat dan pada akhirnya upaya membangun brand menjadi brand yang top-of-mind dapat tercapai.

\section{Daftar Pustaka}

Aaker, D. (1991). Managing Brand Equity. New York, Free Press.

About. "What is Branding and How Important is it to Your Marketing Strategy?". About Online. Home page on-line. Available from http:/ / marketing.about.com/cs/ brandmktg/a/whatisbranding.htm; accessed 8 November 2010.

Argenti, Paul A. (2007). Corporate Communication, $4^{\text {th }}$ ed. NY, McGrawHill Companies Inc.

Big girl branding. 2010. “Top 10 Branding Examples Killing It and What You Can Learn From Them". Big girl branding Online. Home page on-line. Available from http://www.biggirlbranding. com/top-10-branding-exampleskilling-it-and-what-you-can-learnfrom-them/; Internet; accessed 2 November 2010.

Business \& Accounting. "Brand Management". Business \& Accounting Online. Home page on-line. Available from http://akuntansibisnis. wordpress.com/2010/06/15/ brand-management/; Internet; accessed 2 November 2010.

Clow dan Baack (2004). Integrated Advertising, Promotion, \& Marketing Communications, $2^{\text {nd }}$ ed. Upper Saddle River, NJ: Pearson Education, Inc.

De Chernatory, L. And McDonald, M. (1998). Creating Powerful Brands in Consumer Service and Industrial Markets. Oxford, ButterworthHeinemann.

Duncan, T. (2002). IMC: Using Advertising and Promotion to Build Brands. Boston, McGraw-Hill Irwin.

Duncan, Tom (2005). Principles of Advertising $\mathcal{E} I M C, 2^{\text {nd }}$ ed. NY, McGraw-Hill Companies, Inc.

Kandau, Marcus (2010). Marcomm \& PR Director. Wawancara, 9 April 2010, Tangerang. Sour Sally Supermall Karawaci, Tangerang

Keller, Kevin L. (2008). Strategic Brand Management, $3^{\text {rd }}$ ed. Upper Saddle River, NJ: Pearson Education Inc

Kriyantono (2008). Teknik Praktis Riset Komunikasi. Jakarta, Kencana

Laforet, Sylvie (2010). Managing Brands. UK, McGraw-Hill.

Nasution (2007). Metode Research (Penelitian Ilmiah). Jakarta, Bumi Aksara.

Nazir, Moh (2005). Metode Penelitian. Bogor, Ghalia Indonesia.

Nica, Vera (2010). "Image Brand Sour Sally di Mata Konsumen".

Seitel, Fraser P. (2004). The Practice of Public Relations, $9^{\text {th }}$ ed. Upper Saddle River, NJ: Pearson Education Inc.

Suarasurabaya.net. (2010). "Konsumsi Yogurt, Dukung Gaya Hidup Sehat". Available from http:// www.suarasurabaya.net/v06/kelan akota $/$ ?id=9def6cbc6a926ffcd40d 92 2f5cebb964200860077 diakses 15 Maret 2010. 